\title{
PESTICIDES IMPORT, USE, CONSUMPTION AND RESIDUE STATUS AMONG FOOD CROPS IN NEPAL: A REVIEW
}

\author{
Dharmendra Kalauni* and Arati Joshi \\ Faculty of Agriculture, Agriculture and Forestry University, Rampur, Chitwan, Nepal \\ *Corresponding author e-mail: kalauni.dharmendra@gmail.com
}

This is an open access article distributed under the Creative Commons Attribution License, which permits unrestricted use, distribution, and reproduction in any medium, provided the original work is properly cited.

\section{ARTICLE DETAILS}

\section{Article History:}

Received 1 August 2019

Accepted 10 September 2019

Available online 19 September 2019

\section{ABSTRACT}

Insubstantial options for chemical pest management compelled farmers to use synthetic pesticides against crop insect pests that created vicious circle of increasing high-dose-pesticides applications in agriculture sector. The study was carried out to understand prevailing situation of pesticides uses and their state regulation status. Secondary data were obtained from Plant Protection Division, Plant Management and Registration Division, and FAOSTAT for drawing inferences and trend analysis. Chemical pest management commenced from using Paris green, Gamaxone, Nicotine sulphate and Chlorinated hydrocarbons in 1950s to 117 chemically defined pesticides including bio-pesticides and bio-rational compounds of 2186 formulations from 1960s to 2018 has made obvious changes in pest management scenario in the country. Per hectare pesticide consumption in Nepal is 396.0 gram (a.i.) while in commercial vegetable sector its consumption is as high as 1,600 gram a.i. per hectare. Option dearth but farmers' reliability only in chemical applications in pest management in crop fields has resulted in repercussion of vicious circle of compelled higher dose pesticide applications in crops. Obvious result is scores of multitudes of pesticides crowded in market in the country. Above all, problems of pesticide residues in food grains and green vegetables are emerging.

\section{KEYWORDS}

Synthetic pesticide, Insecticide, Usage, Crop-residue.

\section{INTRODUCTION}

A pesticide is any substance used to kill, repel, or control certain forms of plant or animal life that are considered to be pests [1]. First known pesticide was the elemental sulfur, whose dust was believed to be used 4500 year ago in ancient Mesopotamia [2]. The Rig Veda, which is about 4000 year old, also mentions the use of poisonous plants for pest control [3]

Until 1950s Nepalese were unaware of modern chemical pesticides and were dependent upon traditional organic techniques for killing pests [4]. In 1955 chemical pesticides were first introduced in Nepal with purpose of malaria control in public health sector, when Paris green, Gamaxone, and Nicotine sulphates were imported from United States of America (USA) [5]. Later in early 1960s, chemical pesticides were introduced in agriculture sector and during mid-sixties, when green revolution started in India, traditional farmers were taught to use agrochemicals specially fertilizers, insecticides and fungicides [4].

A very well-known chemical pesticide; Dichloro-DiphenylTrichloroethane (DDT) made its first impact in 1956. This was soon followed by a variety of other organochlorines (1950s), organophosphates (1960s), Carbamates (1970s), and Synthetic Pyrethroids (1980s) [6]. Till date country do not produce synthetic pesticide and used to import active ingredient. Most of the pesticides were from the India, China, Thailand and Japan [7].

At present in Nepal, there are 219 license owned pesticides importers and 5 formulators [8]. Out of total resellers in the country, 11, 908 resellers have received training on safe use of pesticides and storage management, 12,887 license holders have been selling the pesticides through agro-vets. At present 2,576 types of pesticides by trade name \& 139 pesticide by common names have been registered for use under Pesticides Act 1991 and Rules 1993 [8]. Therefore this study was conducted with a principal object to investigate the current status of the pesticide use, pesticides residue in food crops and pesticide market within in the country. Further our study tried to compare the country status of pesticide use with other country to some extent.

\section{MATERIALS AND METHODS}

The study was based on time series secondary data for twenty years that were obtained from publications of Plant Protection Division, Plant Management and Registration Division, and FAOSTAT. It also includes review of nearly four dozen of literature that include journal articles, dissertation, government and private sector reports, and websites.

Data were assembled and graphs were generated with the help of Microsoft Excel Software. Linear trend line analysis was carried for estimating the average annual change. Mathematically Expression for Linear Trend Line;

$\mathrm{Y}=\mathrm{a}+\mathrm{bT}$ where; $\mathrm{Y}$ is a pesticide use ( $\mathrm{kg}$ of active ingredients) at $\mathrm{T}, \mathrm{b}$ is an average annual growth $(\mathrm{Kg}), \mathrm{T}$ is a time factor in years and a is an intercept

Percentage change was estimated as,

Percentage $(\%)$ change $=\mathrm{X} 2-\mathrm{X} 1 / \mathrm{X} 1 * 100$

\section{RESULTS AND DISCUSSION}

\subsection{Pesticide Import in Nepal}

Pesticides are used in agriculture to boost the yield, improve the quality, and extend the storage life of food crops [9]. In Nepal pesticide consumption is increasing mostly in the areas near market or highway corridor [10]. According to the latest estimate in fiscal year 2016/17, the annual import of pesticides in Nepal was reported 635.72192 ton (active ingredient) which was worth of NRs. 747, 785, 916.64 (USD 6, 690, 997.82) [8]. In global context, China was reported with highest pesticide use of 1.81 million tonnes in year 2014 [11]. Zhang [12] also reported China as major global economy with major share on pesticide production, import and consumption. 


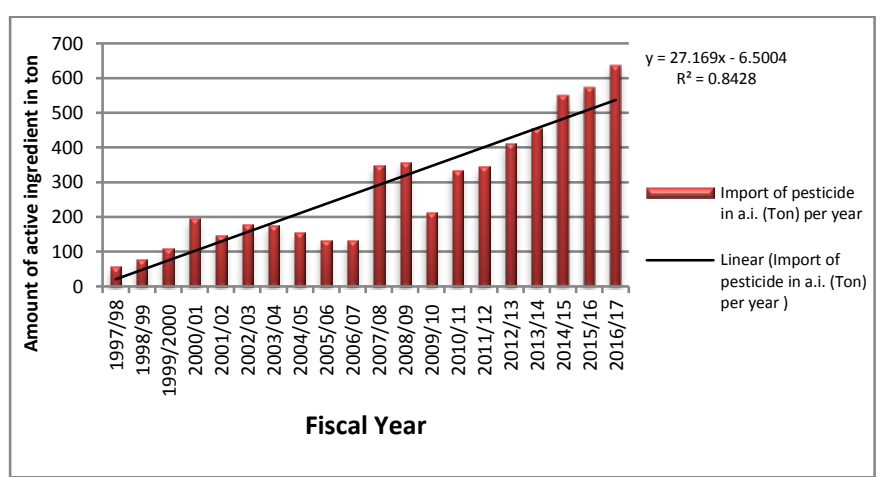

Figure 1: Import of Pesticide in Nepal.

(Source: Pesticide Management and Registration Division , 2018)

Import of the pesticides in Nepal for last twenty years was in increasing trend and linear trend line showed that annual increase in pesticide import was 27.16 ton as shown in figure 1.

Calculation of the percentage change showed that highest increase of the pesticides import was in the fiscal year $2007 / 08$ by about $164.68 \%$ as shown in figure 2. After 2006/07, significant increase in pesticide use was probably due to increased application on high-value vegetable production which has replaced low-earning cereal crops in the hill region [7]. Economic Survey (2007/08) also reported that in that very year use of pesticide in health sector was also greater than past year because of extensive Kalazar, Malaria control program running in 11 districts of Nepal. Extension services of Department of the Agriculture (DoA) also played vital role in stimulating use of chemical pesticides to increase the production [13]. It was found that in the first decade, from the base year $1997 / 98$ to $2006 / 07$ there was $133.719 \%$ change in pesticide import. While in next decade from $2007 / 08$ to $2016 / 17$ there was $82.944 \%$ change in pesticide import in the country.

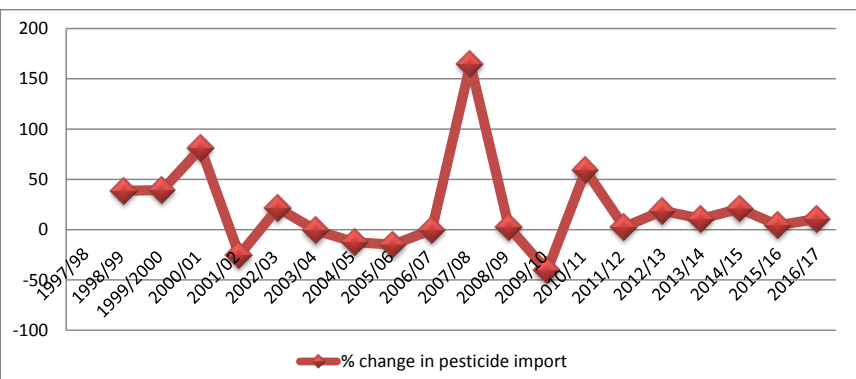

Figure 2: Percentage change in pesticide import.

(Source: Pesticide Management and Registration Division , 2018)

\subsection{Use of Different Types of Pesticides in Nepal}

Pesticide use in agriculture sector become indispensable in least developed country like Nepal where farmers need a quick, efficient and cheap method to get rid of the pest and to prevent pest problem in the field [14]. This has resulted high competition in the sale of pesticides in the country. Insecticides, fungicides, herbicides, bactericides, acaricides, rodenticides, molluscicides, bio-pesticides, and the herbal products are the types of pesticides used in Nepal [8]. Among different types of the available pesticides in market, fungicide was used in highest amount followed by insecticides, herbicides and other as shown in figure 3. Where, other category includes pesticides like bactericides, acaricides, rodenticides, molluscicides, bio-pesticides and herbal products are included. G.C [15] also reported that fungicides are used in the greatest quantity, followed by insecticides, herbicides, bio-pesticides, rodenticides and acaricides.

However, across the globe among the major category of pesticides used, herbicide was reported to have highest consumption follwed by inseticides, fungicide or bactericides, rodenticides, etc[11]. A. De et. al, [16] also reported similar findings where herbicide shared about $47.5 \%$ of global consumption, inseticide shared $29.5 \%$, fungicide shared $17.5 \%$ and other types of pesticides shared about $5.5 \%$ of worldwide consumed pesticides.

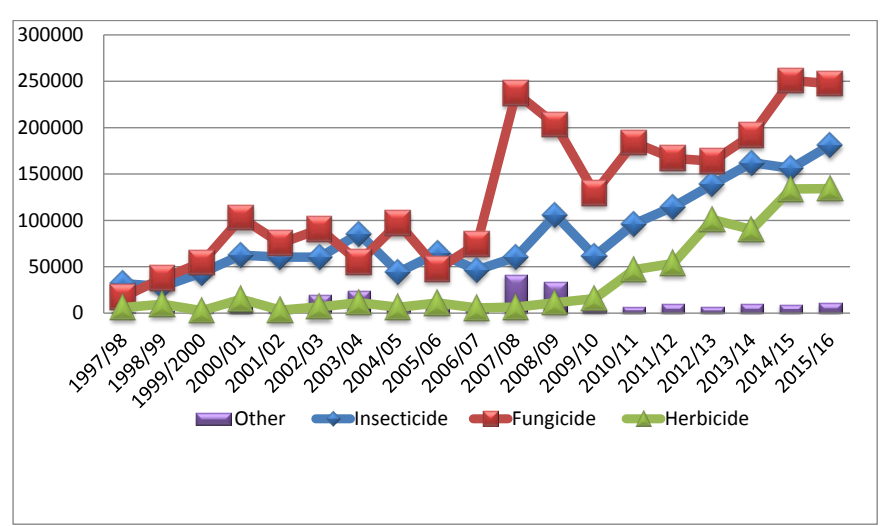

Figure 3: Different Types of Pesticide used.

(Source: Pesticide Management and Registration Division , 2018)

The linear trend line showed that growth in use of fungicides was 11,511 Kg active ingredient per annum while that of insecticide and herbicide was 7,219.7 and 6,497.6 Kg active ingredient per annum. Thus, linear trend line also confirmed increase in use of fungicide was higher than other type of pesticide in the country.

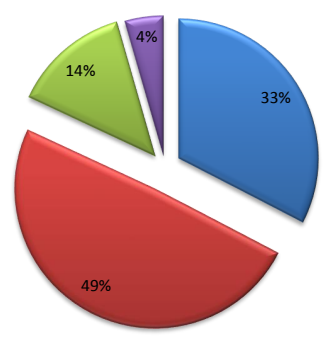

Insecticide

I Fungicide

Herbicide

๑ Others

Figure 4: Share of Different Pesticide in Total Annual Pesticide Use.

(Source: Pesticide Management and Registration Division , 2018)

In 2015/16, out of total amount of the pesticide consumed in the country, fungicide share major part of pesticide used (49\%), followed by insecticide (33\%), herbicide (14\%) and others (4\%) as shown in figure 4.

\subsection{Different Nature of Chemical Insecticide Used in Nepal}

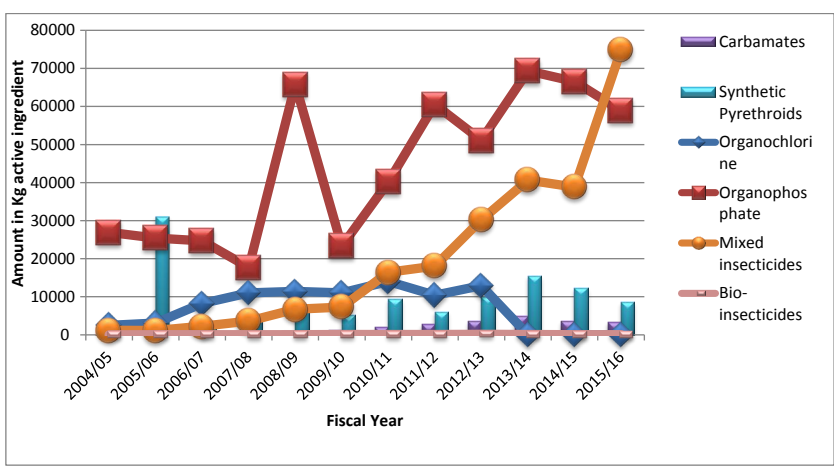

Figure 5: Different Nature of Insecticide in Use.

(Source: Pesticide Management and Registration Division , 2018)

Farmers are using a number of insecticides based on their chemical nature and composition such as organophosphate, synthetic pyrethroid, organochlorine, bio-insecticide, mixed type of insecticide [8]. PPD [10] reported that among such diverse nature of insecticides available in the market, farmers' preferences for the organophosphate types was relatively higher. However, in recent years preference and use of mixed insecticide was also increasing as shown in figure 5 . Linear trend line also showed that annual increase in the use of the mixed insecticide and the organophosphate was $5,571.9 \mathrm{Kg}$ a.i. and 4,205.8 $\mathrm{Kg}$ a.i. respectively.

Similarly, percentage change was calculated for organophosphate and mixed insecticides from $2004 / 5$ to $2015 / 16$ as shown in figure 6 . Estimation of total average change of the mixed insecticide and 
organophosphate from 2004/05 to 2015/16 showed use of mixed insecticide was quiet high as compared to the organophosphate as shown in figure 6 . These facts gave a clear indication of the increased use of mixed insecticide in the country which was mainly due to recent increased preference of farmers because of its broad-spectrum nature, higher toxicity and more effective results.

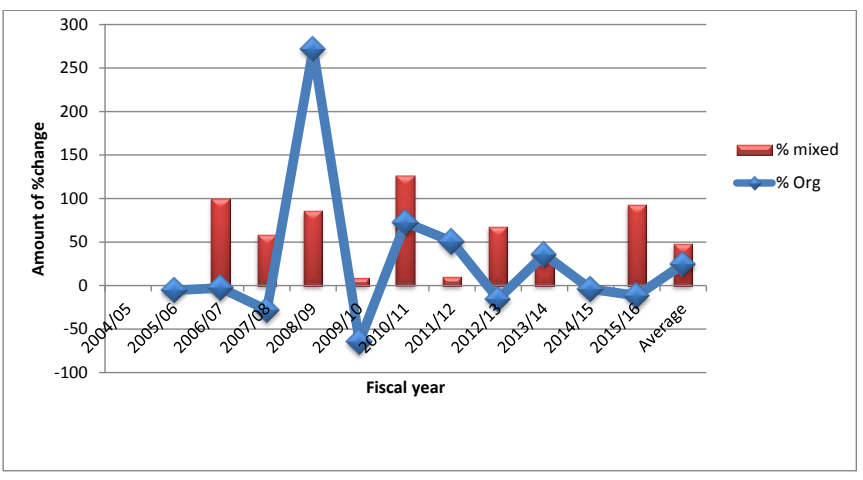

Figure 6: Percentage change in major insecticides.

(Source: Pesticide Management and Registration Division , 2018)

Due to imposed ban on Organochlorine insecticides by government of Nepal because of harmful effect such as residual problem and health hazards, import of such types of pesticides was nil from fiscal year 2013/14. Further, use of Synthetic pyrethroids type of insecticide was more compared to Carbamates type as shown in figure 5. Twenty one hazardous pesticides had already been banned, namely Aldrin, Benzene hexachloride, Chlordane, DDT, Dieldrin, Endosulphan, Endrin, Heptachlor, Lindane, Methyl parathion, Mirex, Monocrotophos, Organo mecurial Fungicides, Phorate, Phosphamidon, Toxafen Carbofuran, Dichlorvos, Triazophos, Carbaryl, and Benomyl for marketing across the country [8, 17].

\subsection{Pesticide Consumption}

In global context, pesticide use has grown to 3.5 billion Kg active ingredients per year [18]. Europe is now the largest pesticide consumer in the world, second being Asia [19]. As for country, Colombia, China, United Kingdom, France, Brazil, Japan, and the United State, are the largest pesticide importers, consumer or traders of the world [11]. Colombia's pesticide use per hectare of cropland reached highest $(20.79 \mathrm{Kg} / \mathrm{ha})$ of all country across the globe, followed by china $(14.82 \mathrm{Kg} / \mathrm{ha})$ in year 2014 [20]. While some countries such as UK, France, Denmark and Japan had reduced pesticide use over the past two decades but in most regions of the globe it is considerably increasing [18].

In context to Nepal, during the $19^{\text {th }}$ century, population growth influenced the process of intensification of agriculture, and led to opening up of virgin lands for cultivation, especially in the Terai [21]. In the 1950s, the eradication of malaria in many areas of the Terai and the clearance of forests accelerated the migration of hill people, as well as people from India, to the Terai. At that very time pesticides made their first impact in the public sector through the malaria eradication program [9]. Then after in mid-sixties (1960s) pesticides were used in agriculture sector and household. At present, consumption of pesticides in agriculture sector was significantly higher compared to public health sector as shown in figure7.

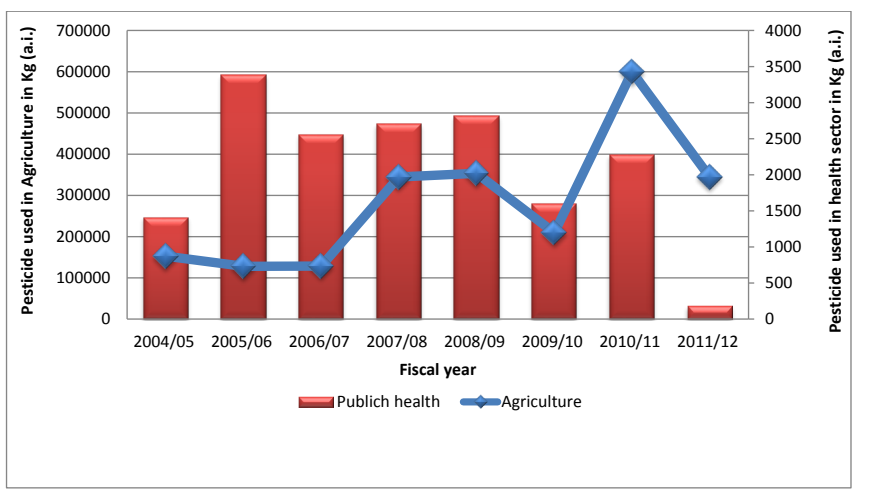

Figure 7: Pesticide use in Different Sector.

(Source: Pesticide Management and Registration Division ,2018)
A study carried out by the International Union for Conservation of Nature (IUCN) in 1955 reported that national average consumption of pesticide in Nepal was 142 gram active ingredient/ha [22]. But the recent study conducted by the Plant Protection Directorate (PPD) stated the national average consumption of pesticide as 396 gram active ingredient/ha which is almost three times (2.788 times) higher than the past national average consumption value reported by IUCN. However, it was less than world average of $0.5 \mathrm{~kg}$ a.i. $/ \mathrm{ha}$.

Among different development regions of Nepal, PPD, (2014) reported that the average per hectare consumption of pesticides in Far-Western Development Region (FWDR), Mid-Western Development Region (MWDR), Western Development Region (WDR), Central Development Region (CDR) and Eastern Development Region (EDR) was 0.146 a.i. $\mathrm{Kg} / \mathrm{ha}, 0.225$ a.i. Kg/ha, 0.276 a.i. $\mathrm{Kg} / \mathrm{ha}, 1.015$ a.i. Kg/ha, 0.616 a.i. Kg/ha respectively. While on ecological basis, highest average pesticides consumption was in Terai $(0.995$ a.i. $\mathrm{Kg} / \mathrm{ha}$ ) followed by valley $(0.470$ a.i. $\mathrm{Kg} / \mathrm{ha}$ ), hill (0.314 a.i. $\mathrm{Kg} / \mathrm{ha}$ ) and high hill (0.085 a.i. Kg/ha) [10]. Joshi et al [21] also reported use of pesticides was increasing in the Terai and more accessible areas, while smallholders had a limited access to these inputs in the hills and mountains.

\subsection{Pesticide Application and Residue in Food Crops}

Pesticide use was much more in areas with intensive commercial farming of vegetables, tea, and cotton $[23,24]$. Presence of pesticides in food commodities had been always a matter of serious concern [25]. In commercial vegetable production up to 1600 gram active ingredient/ha was used [10]. Sitaula \& Atreya [26] reported that more than $90 \%$ of the total pesticides in the country are used in vegetable farming.

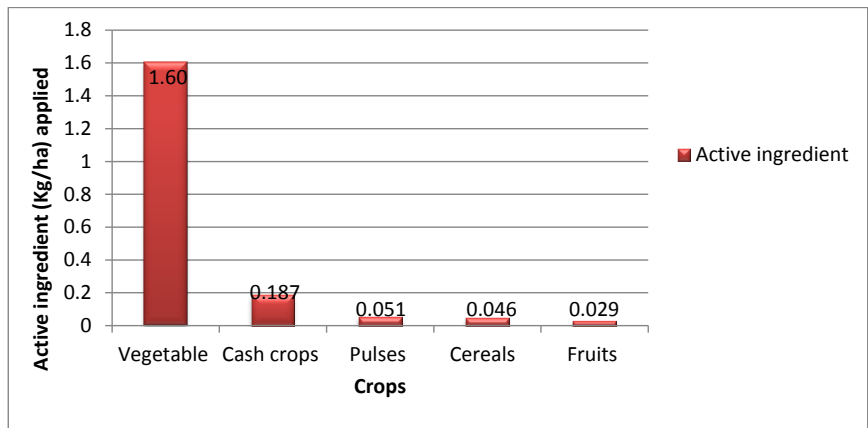

Figure 8: Pesticide Application

(Source: Plant Protection Division, 2014)

Pesticides application was also higher in the vegetable followed by the cash crops, pulses, cereals, and fruits as shown in figure 8. Aryal et.al., [27] reported that the frequency of application of pesticides in top cash crops like potato, tomatoes, cauliflowers, cabbage, beans, tomato, ladyfinger, bitter gourd, pumpkin, cucumber and bottle gourd was as higher as about five applications per cropping season. Shrestha and Neupane, [28] also reported that frequency of application of pesticide in Potato, Tomato, Cabbage, Bittergourd and Cucumber was $2-15$ times per cropping season whereas Rice, Maize, Wheat and Mustard are treated 1 - 3 times per crop cycle. The most pesticide usage, up to 25 applications per year was found in Tea [7].

Among different cultivated vegetables, eggplant had the highest pesticide usage with $67 \%$ of farmers spraying eggplant crops more than eight times and $25 \%$ of farmers spraying four to six times per crop [7]. National survey on the pesticide consumption statistics in Nepal showed that the highest level of pesticide use was observed on eggplant (3.34 a.i. $\mathrm{Kg} / \mathrm{ha}$ ), which was much higher than on any of the other arable crops. Tomato crops $(1.95$ a.i. $\mathrm{Kg} / \mathrm{ha}$ ) were next highest followed by cotton (1.5 a.i. $\mathrm{Kg} / \mathrm{ha})$, potato (1.03 a.i. $\mathrm{Kg} / \mathrm{ha}$ ) and cole crop (0.70 percent a.i. $\mathrm{Kg} / \mathrm{ha}$ ) [10].

Koirala et al., [29] reported highest level of contamination in root vegetables followed by leafy vegetables. Rawal et al., [30] also reported that estimated average daily intake (EADI) of dichlorovos exceeded the acceptable daily intake (ADI) in 18 vegetables. Residues analysis of 75 samples of 13 vegetables carried out by Sharma, (2015) reported that $4 \%$ of the total samples were reported to have above maximum residue limit (MRL). Sharma, [31] found that higher concentration of Cypermethrin was found in tomato and brinjal, Deltamethrin was found the highest in 
cowpea and similarly Carbandazim and Mancozeb concentration were highest in tomato followed by bottle guard and chilli. More than $50 \%$ of the tea samples from Jhapa were found to be contaminated with different pesticides where even a banned pesticide named Ethion was reported [30].

Rapid Bioassay Pesticide Residue (RBPR) analysis unit at Kalimati showed that in year 2016/17 out of the total 1903 tested samples, 5 need quarantine and 22 samples need to be disposed [32]. With the increasing threat of pesticide residue and contamination government had taken some initiatives to set maximum residue limit for some agriculture produce. Food Act 1967 and Food Regulation 1970 in Nepal had established and implemented Maximum Residue Limit (MRLs) for pesticides in food products, but that is limited to cereals, pulses and their products, bottled water and infant foods commodities [33, 34]. Recently, Department of Food Technology and Quality Control (DoFTQC) proposed the set of MRLs of Pesticides for Fruit (Apple, Banana), Vegetable (Bitter gourd, Egg Plant, Cabbage, Cauliflower, Okra, Potato, Tomato) Tea (Green tea, black teafermented and dried) [35]. This was supposed to be effective from September 2019.

\section{CONCLUSION}

Import of the pesticides is increasing mainly due to increased use of the chemical pesticides in the agriculture sector because of increasing dependency on synthetic pesticides for crop protection. Heavy use of chemical pesticide in market oriented agricultural commodity like vegetable, cash crop is common practice with commercialization of agriculture. Fungicide is the dominant type of pesticide used in the country followed by insecticide, and herbicide. Among different kinds of insecticides used in country, mixed insecticides and organophosphate are the major one. Amount of bio-pesticide or botanical pesticide used in the country is very low as compared to synthetic pesticides. Pesticide use is highest in Teria and increasing rapidly near market area and highway corridors. Among all the development regions, Central Development Region has the highest pesticide consumption of 1.015 a.i. $\mathrm{Kg} / \mathrm{ha}$. Application of pesticide is higher in agricultural commodities like brinjal, tomatoes, root vegetable, leafy vegetable, etc. Problem of pesticide residue is blooming, with lack of proper testing and monitoring agency.

\section{RECOMMENDATION}

Research and study play very important role in identification and commercialization of alternative means of crop protection which are less hazardous, more sustainable and eco-friendly. So, there should be some provision of government and private sector to provide seed funding in developing such innovation in the field of crop protection. Government and private sector interventions are highly recommended to promote the use of botanical and bio-pesticides through enough incentives to reduce dependency in synthetic pesticide.

In country, there is serious need of pesticide accreditation laboratory. Government should adopt proper and regular mechanism of monitoring pesticide residue in agricultural commodity. Quarantine check point in each province will help to prevent illegal trade of pesticide and also help to monitoring the pesticide contaminated vegetables, fruits, etc. To control and monitor the excessive pesticide residue in agricultural produce it is necessary to establish well equipped modern laboratory in the major vegetable and fruit collection and distribution center for rapid and effective test. However, country mostly has Rapid Bioassay of Pesticide Residue (RBPR) analysis units which cannot detect other pesticides then organophosphate, carbamates and detectable fungicides.

\section{ACKNOWLEDGEMENTS}

We are highly delighted to acknowledge consistent support provided by Assistant Prof. Shiv Chandra Dhakal, Assistant Professor Suryamani Dhungana and Assistant Prof. Rishi Ram Kattel in preparing manuscript.

\section{REFERENCES}

[1] NIEHS. National Institute of Environmental Health Sciences. $\begin{array}{llll}\text { Retrieved May } & 13, & \text { 2019, } & \text { from }\end{array}$ https://www.niehs.nih.gov/health/topics/agents/pesticides/index.cfm

[2] Wikipedia. Wikipedia, The Free Encyclopedia. Retrieved May 13, 2019, from https://en.wikipedia.org/wiki/Pesticide
[3] Rao, G.R., Rupela, O.P., Rao, V.R., Reddy, Y.V. 2007. Role of Biopesticides in Crop Protection: Present Status and Future Prospects. Indian Journal of Plant Protection, 35, 1-9.

[4] Kansakara, V.M. 2001. Use of Insecticides. Kathmandu: Inernational Workshop Developing Countries.

[5] Dahal, L. 1995. A Study on pesticide pollution in Nepal. Kathmandu: IUCN.

[6] Neupane, F.P. 2001. Synopsis of Use and Economic Value of Pesticides and Chances for Reduced Application Rates at Different Scales in Hindu Kush Region. Kathmandu, Nepal: Center for Environmental and Agricultural Policy Research, Extension and Development (CEAPRED)

[7] Winrock International. 2014. Knowledge -based integrated sustainable agriculture and nutrition (KISAN) project pesticides evalaution report and safer use action plan (PERSUAP). Washington, DC: USAID.

[8] Pesticide Management and Registration Division. 2018. List of Registered Pesticides in Nepal. Harihar Bhawan, Lalitpur: Pesticide Management and Regulation Division (Pesticide Management and Registration Division), Plant Protection Directorate (PPD), Department of Agriculture.

[9] Fernndez-Alba, A., Garca-Reyes, J. 2008. Large scale multi residue methods for pesticdes and thier degradation products in food by advanced LC-MS. Trac-Trend. Analytical Chemistry, 973-990.

[10] PPD. 2014. Survey on National Pesticide Consumption Statistics in Nepal. Harihar Bhawan, Lalitpur: Plant Protection Directorate (PPD), Government of Nepal.

[11] Roser, M., Ritchie, H. 2017. Our World in Data. Retrieved 2018, from https://ourworldindata.org/fertilizer-and-pesticides.

[12] Zhang, W. 2018. Global pesticide use: Profile, trend, cost / benefit and more. Proceedings of the International Academy of Ecology and Environmental Sciences, 1-27.

[13] NPC. 2004. Enhancing the Competitive Strength of the Nepalese Agricultural Produces. Singh Durba, Kathmandu: National Planning Commission Secretariat, Central Monitoring and Evaluation Division, Government of Nepal.

[14] Atreya, K., Sitaula, B.K., Johnsen, F.H., Bajracharya, R.M. 2011. Continuing Issues in the Limitations of Pesticide Use in Developing Countries. Journal of Agriculture Environment Ethics, 49-62.

[15] Yubak Dhog G.C. 2018. Status of plant protection activities in Nepal. Retrieved 2018, from IPPC: https://www.ippc.int/static/media/files/publications/1310180880_21b _Nepal2.pdf

[16] De, A., Bose, R., Kumar, A., Mozumdar, S. 2014. Worldwide Pesticide Use. In in Targeted delivery of pesticides using biodegradable polymeric nanoparticles, New Delhi: Springer, 5-6.

[17] Sharma, D.R. 2019. Status of Chemical pesticides use and their regulation in Nepal. Hariharbhawan, Lalitpur: Plant Quarantine and Pesticide Management Center.

[18] Eyhorn, F., Roner, T., Specking, H. 2015. Reducing pesticides use and risk - What action is needed? Switzerland: Helvetas. 2015.

[19] Zhang, W., Jiang, F., Ou, J. 2011. Global pesticide consumption and pollution: with China as a focus. Proceedings of the International Academy of Ecology and Environmental Sciences, 125-144.

[20] FAOSTAT. 2018. Food and Agriculture Organization of United Nation. Retrieved November 2018, from http://www.fao.org/statistics

[21] Joshi, K.D., Conroy, C., Witcombe, J.R. 2012. Agriculture, seed, and innovation in Nepal: Industry and policy issues for the future. $2033 \mathrm{~K}$ Street, NW | Washington, DC: International Food Policy Research Institute.

[22] Thapa, R. 1997. An overview of Pesticide pollution in Nepal. Nepalese Horticulture, 31-39. 
[23] Jayana, B., Pant, S., Prasai, T., Jasmine, D. 2008. Study on major pesticides and fertilizers used in Nepal. Scientific World, 76-80.

[24] Giri, N. 2010. Pesticide Use and Food safety in Kathmandu Valley/Nepal. Institute of soil research University of Natural resources and life science.

[25] Sharma, D., Thapa, R., Manandhar, H., Shrestha, S., Pradhan, S. 2012. Use of pesticide in Nepal and impacts on human health and environment. Journal of Agriculture and Environment, 67-74.

[26] Sitaula, B., Atreya, K. 2010. Mancozeb: growing risk for agricultural communities in Himalaya. Journal of Sciences.

[27] Aryal, K., Neupane, S., Lohani, G., Jors, E., Neupane, D., Khanal, P., 2013. Health effects of pesticdes among vegetables farmers and the adaptation level of IPM program in Nepal. Kathmandu: Nepal Health Research Council.

[28] Shrestha, P.L., Neupane, F.P. 2002. Socio-economic contexts on pesticide use in Nepal. Landschaftsökologie und Umweltforschung, 38, 205-223.

[29] Koirala, P., Khadka, D., Dhakal, S., Lama, J. 2007. Common tea pests and pesticides use in Nepal. Journal of Food Science and Technology Nepal, 1816-0727.
[30] Rawal, S.D., Rana, N., Shrestha, S., Sijapati, J. 2012. Assessment of Pesticide Residue In some vegetable grown in Kavrepalanchok and Bharatpur districts. Nepal Journal of Science and Technology, 13, 45-50.

[31] Sharma, D.R. 2015. Use of Pesticides and its Residue on Vegetable Crops in Nepal. The Journal of Agriculture and Environment, 33-42.

[32] PPD. 2017. Year wise compilation of rapid bioassay of pesticide residue analysis results of RBPR analysis unit at Kalimati, indicate the increasing trend of the residue in the vegetable crops. Kathmandu: Plant Protection Directorate (PPD).

[33] Lama, J. 2008. Standard setting on pesticide residue to ensure food safety. The journal of Agriculture and Environment, 2008. 46-53.

[34] Koirala, P., Tamrakar, A. 2008. Analytical capability on pesticide analysis in food in Nepal. Proceedings of 5th National Seminar, Kathmandu: Nepal Academy of Science and Technology, 10-12.

[35] Himalayan News Service. 2018. Govt to define residue limit of pesticides, chemicals in every vegetable, fruit. Retrieved 2019, from Himalayan Times: https://thehimalayantimes.com/business/govt-todefine-residue-limit-of-pesticides-chemicals-in-every-vegetable-fruit/ 